\title{
THE ELECTORAL COMMISSION OF GHANA AND THE ADMINISTRATION OF THE 2012 ELECTIONS
}

\author{
J Shola Omotola
}

\begin{abstract}
Ghana's Fourth Republic has a reputation for having a reasonably high degree of institutionalisation in election administration. Its electoral and democratic success stories have largely been associated with the autonomyenhancing institutional design and leadership of the Electoral Commission of Ghana (ECG), which engender a degree of public confidence and trust. The 2012 elections, however, produced an ominous twist in the hitherto sacrosanct nature of democratic legitimacy in Ghana. This article assesses the role of the ECG, drawing on the quality of the elections, measured by the level of participation, competitiveness and legitimacy, as well as the actions and inactions of the ECG at critical stages in the electoral cycle. Overall, the ECG could be adjudged to have done well, especially on the first two indicators, given the high level of voter turnout ( $80.15 \%)$ and the closeness of the total votes and seats won by the ruling National Democratic Congress and the main opposition, the New Patriotic Party. However, the legitimacy of the election was fiercely challenged with the opposition's rejection of the results and attendant litigation in the Supreme Court. The problem may have been accentuated by the new political economy of oil and the strong desire to access and control oil windfall, the messy application of biometric voter verification as a result of the malfunctioning of the equipment and the controversy over the delimitation of 45 new constituencies in a manner interpreted by opposition parties as gerrymandering. It seems these are not heady days for Ghana's democracy. Rising levels of adversarial elite behaviour not only pose serious democratic threats they raise questions about the depth of the much touted institutional foundations of the country's democracy.
\end{abstract}

\section{INTRODUCTION}

Since the inception of the Fourth Republic in 1992 Ghana has developed a reputation for a reasonably high degree of institutionalisation in the administration of its elections. This is partly the result of the degree of public confidence and trust 
in the independence, professionalism and political impartiality of the Electoral Commission of Ghana (ECG), which tends to make all political actors accept the results of elections. For example, while the opposition parties bitterly contested the results of the 1992 presidential election, the losing parties accepted the outcomes of the elections of 1996, 2000, 2004 and 2008 (Omotola 2012, 2010a; Gyimah-Boadi 2009). This is important because the losers' acceptance of election results is an important component of democratic legitimacy. It presupposes that both voters and candidates believe that election administrators have complied substantially with the electoral rules (Lindberg 2004; Rakner \& Svasand 2003).

Though not totally flawless, especially given the protracted controversy that surrounded the 1992 founding elections (Gyimah-Boadi 1994; Oquaye 1995, 2000), there is now a broad consensus domestically and internationally that the electoral process in Ghana 'functions pretty well' (Nugent 2005, p 2). Elsewhere, Nugent (2001, p 405) posits that Ghanaian politics, particularly the 2000 elections, ushered in 'an impressive measure of political pluralism' because it 'presented the first test of the workability of the constitutional limits on presidential tenure, as well as the first real opportunity to achieve a peaceful change of power through the ballot box' (also quoted in Gyimah-Boadi 2001, p 103 and Smith 2002, p 622). Walraven (2002, pp 186-187) also notes that 'there was great satisfaction among Ghanaians about the conduct of the polls'. Although there were various irregularities, 'none ... appeared very significant or structural' or raised questions about the legitimacy of the process (see also Gadzekpo 2000).

In a comparative exploration by the Michigan State University-based AfroBarometer, devoted to the quantitative study of elections in Africa, Ghanaians expressed strong 'faith in elections as a means to represent the true voice of the people in government'. They also expressed the greatest confidence in the effectiveness of their votes (AfroBarometer 2006, p 2). Local and international observers and commentators also hailed the 2008 elections as highly successful (Omotola 2010a; Gyimah-Boadi 2009). Gyimah-Boadi \& Brobbey (2012,p 2) attribute the effectiveness of election administration in Ghana to 'the success of transparency- and fairness-enhancing reforms to the electoral process in the mid-1990s', which 'proved resilient enough to survive the intense competition of the 2000 and 2008 polls ... and produce two electoral turnovers, making Ghana unique among African democracies'.

Ghana's electoral and, by logical extension, democratic, success story has largely been associated with the autonomy-enhancing institutional design and leadership of the ECG, which has been acclaimed both locally and internationally for its credible electoral management over the years. In a more recent comprehensive evaluation of the ECG a consistent student of the Ghanaian democratisation process noted: 
Against the backdrop of failed electoral process in most African countries, the ECG has organized four successful general elections with marginal errors. The most distinguishing factor for the ECG's success were largely, but not exclusively, the making of the electoral process transparent, fostering agreement on the rules of the game and asserting its autonomy in relation to the performance of its mandates.

Debrah 2011, p 25 (Author's emphasis)

The 2012 election, however, reflected an ominous twist in the hitherto sacrosanct nature of electoral/democratic legitimacy in Ghana. Alleging various forms of irregularities, including 'the failure to comply with regulations requiring mandatory biometric verification, failure by Presiding Officers at some polling stations to sign the official results sheet, "over-voting" at a number of polling stations, and discrepancies in the size of the voters register', the New Patriotic Party (NPP) challenged the outcome not only of the presidential election but of more than 10\% of the parliamentary results (Gyimah-Boadi 2013, p 5).

The Supreme Court handed down its judgement on 29 August 2013, upholding the results declared by the ECG. However, the fact that the NPP was moved to petition the court to declare the election invalid, along with the two dissenting voices on the nine-man bench, suggest that all did not go well, even if the irregularities were insufficient to warrant total cancellation and/or a rerun.

What factors account for the changes in the democratic quality of the 2012 elections, resulting in the opposition's rejection of results and the attendant litigation? In what ways and to what extent can the reversal of gains be linked to the actions and/or inaction of the ECG? What can be done to restore public confidence in the ECG's credibility and professionalism? These are the main questions this article seeks to explore, with the aim of providing a critical appraisal of the ECG's administration of the elections.

Until now the ECG has been regarded as one of the most vibrant institutional foundations of Ghana's successful democracy and it is crucial that efforts be made to ensure that its reputation, based on factors such as its administrative and financial autonomy, political neutrality and impartiality, capacity and professionalism, as well as public confidence and trust, real or imagined, is restored and sustained.

\section{AN OVERVIEW OF THE ECG}

From 1950 to 1968 and from 1974 to 1977 (Ayee 1998, p 54) the ECG was a department of the Ministry of Local Government. Between those periods, and ever since, attempts have been made to institute an independent electoral body: 
either individual commissioners, as was the case in 1968, 1969-74, 1977, 1978, 197882, or a collective body, as in 1982-1992, 1992, 1993 (Ayee 1998, p 54) and to date.

The ECG's responsibilities, as set out in Article 45 of the 1992 Constitution, include compiling and revising the electoral register, demarcating and revising electoral boundaries, the conduct and supervision of public elections and referenda, education of citizens on the electoral process and other such functions that may be prescribed by law.

The commission also has wider responsibilities - it may assist in resolving conflicts between and within political parties. In this way, 'the ECG helps to establish and strengthen internal democratic procedures within the parties by supervising their primaries and certifying the outcomes of internal electoral processes' (Zounmenou 2009, pp 5-6). The ECG is thus the principal organ for the administration of elections in the country.

The ECG currently consists of seven members - a chairman, two deputies (one in charge of operations, the other in charge of finance and administration) and four other members. These seven members are appointed by the president in consultation with the Council of State, a body of eminent citizens partly elected and partly appointed, to advise the president and other state institutions on the discharge of their functions.

The current independent model has statutorily guaranteed mechanisms to ensure and protect the administrative and institutional autonomy of the electoral commission, without which it might easily be manipulated by the executive. Specifically, the 1992 Ghanaian Constitution and the 1993 Electoral Commission Act (known as Act 451) ensure the autonomy of the ECG in three ways. One, the ECG is not placed directly under the control of any person or authority. Specifically, Article 46 of the Constitution provides that 'except as provided in this constitution or in any other law not inconsistent with this constitution, in the performance of its functions the ECG shall not be subject to the direction or control of any person or authority (Constitution 1992, 39; also quoted in Debrah 2011, p 31).

Two, members of the ECG enjoy the same conditions of service as the justices of the superior court, meaning that they occupy office until they attain the mandatory retirement age of 70 . Thus they have security of tenure, which guarantees that once appointed they cannot be removed except for reasons of infirmity or insanity, which must be confirmed by an independent medical board: 'members of the ECG cannot be dismissed by anybody except on grounds of incapacitation arising from ill-health' (Constitution 1992, p 27). The commission is funded directly by the Consolidated Account, meaning that the executive cannot cut off funds to the commission.

It is vital that the ECG, in discharging its duties, lives up to popular expectations and is sufficiently protected by the statutory provisions regarding 
its autonomy. The next section offers some insights into these concerns as a background to the evaluation of its performance in the 2012 elections.

\section{THE ECG AND ELECTION ADMINISTRATION UNDER THE FOURTH REPUBLIC}

Despite the fact that the ECG is presidentially constituted the commission has always strived to demonstrate a reasonable measure of independence, competence and legitimacy in the discharge of its responsibilities. In part, this has to do with the deep institutionalisation of the commission and the institutional-political frameworks that surround it, particularly the political parties, the Inter-Party Advisory Committee (IPAC) - which was established in March 1994 and is funded largely by the donor community, civil society, mass media and the political leadership.

It is important to recall that Ghana's Fourth Republic was effectively launched by the 1992 founding presidential election, which was administered by the Independent National Electoral Commission of Ghana (INEC), constituted under President Jerry Rawlings's Provisional National Defence Council (PNDC). As it turned out, the elections were discredited both locally and internationally. The objections were so serious that opposition parties boycotted the parliamentary elections. Some of the shortcomings identified included the lack of independence of the INEC and attendant electoral irregularities and corruption (Gyimah-Boadi 1994; Oquaye 1995). However, by 1996 several of the major controversial issues had been resolved through IPAC. The reason for the establishment of IPAC, according to Debrah (2011, p 37) was two-pronged: 'first to diffuse opposition-government conflict and tension, and second, get the political parties to establish compromises on the rules of electoral competition'.

The positive impact of IPAC on the electoral process, according to Frempong (2008, p 191), showed in the 1996 elections and has continued. This is evident from the impressive level of voter turnout in 1996, which was established at $73.5 \%$. More importantly, 'the general mood following the election confirmed the fact that the contending political leaders had agreed upon the basic rules of electoral politics' (Ninsin 1998, p 194, cited in Frempong 2008, p 191). Again, unlike in 1992, the defeated presidential candidates readily conceded defeat and congratulated the winner, who, in turn, congratulated the losers on their competitive spirit. Ever since then, the IPAC, an institutional mechanism for consensus building, has been sustained and replicated at regional and district levels. This has continued to aid the ECG in simplifying its electoral tasks. 
Other areas of election administration in which the ECG has performed creditably, according to Freempong (2008, pp 191-192), include:

- It has asserted its independence in many respects over the years. In March 2004, for example, when the NPP government announced the establishment of a national procurement committee to undertake purchases for Election 2004, the ECG contended that such an action would undermine its independence, and had the plan shelved. Similarly, the ECG resisted all attempts by opposition parties to prevent the inclusion of 30 newly-created constituencies in the conduct of Election 2004. The commission, conscious of the fact that it had operated within its mandate in creating the new constituencies, maintained its stand until it was confirmed by a Supreme Court decision (Boafo-Arthur 2006, p 43).

- The ECG has taken even small controversies seriously and has taken innovative steps to deal with them. Before the 2000 elections, candidates' names on the ballot paper appeared in the order in which they filed their nominations. In 1996 this led to a mad rush to secure the top spot on the ballot paper. In 2000 the ECG resolved the matter by introducing balloting for positions on the ballot paper after parties have filed their nominations. It is significant to note that since then this method has been replicated for intra-party elections.

- The ECG, playing its neutral role, was also mindful of the religious dimension. On 24 November 2000 it organised a prayer and fasting session at its conference hall (Agyeman-Duah 2005 p 115).

- The manner in which the ECG has collaborated with donor agencies, political parties, think tanks, civil society groups and the media has been most impressive. One such collaboration, between the ECG, the International Foundation for Electoral Systems (IFES), the Ghana Association of the Blind (GAB) and Action on Disability and Development Ghana (ADD) in 2002 led to the pilot test of the tactile ballot paper ... Similarly, since 1996, it has accredited domestic poll watchers and ensured their unhindered access to important sites, which has boosted public confidence in the voting and its outcome.

Frempong 2008, pp 191-192

The ECG is generally regarded as having contributed to the high level of internal democracy that has become a feature of civil society organisations in Ghana, where 'the ECG is increasingly called upon to organize, supervise and validate the election of their directing organs' (Lemarchand 1998, p 6). For this reason, 'the ECG 
helps institutionalize democratic procedures and contributes to the legitimacy and validity of a significant segment of Ghanaian civil society' (Lemarchand 1998, p 6).

Beyond these accomplishments, during the 2008 elections, which threatened to end Ghana's reputation as a maturing and consolidating democracy, due largely to heightened tensions in the closing stages of election campaigns and the inter-elections period, leading to widespread fear of a probable outbreak of violence during and after the elections, the ECG brought its professionalism and competence to bear upon the electoral process. Ghana defied the odds (Omotola 2010a). Overall, the 2008 elections were seen, despite occasional hiccups, to have been well administered and a further step towards democratic consolidation (Gyimah-Boadi 2009; Whitfield 2009).

A number of factors help explain the credible performance of the ECG and its rising profile at home and abroad in successive elections before 2012. Firstly, it has been noted that the commission has always demonstrated a 'willingness to engage actively in confidence-building, the development of a transparent management style, where party grievances were addressed before they became serious allegations against the ECG' (Elklit \& Reynolds 2002, p 103). Secondly, the commission has also been said to have taken the opposition's complaints about the 1992 elections into consideration in subsequent elections. Moreover, the ECG also has a relatively independent source of funding because it prepares its own budget, which is subject only to the approval of Parliament.

More importantly, the relative independence of the ECG, which has aided its professional performance, relates to the fact that the chairman and two deputies have the same terms and conditions of service as justices of the Court of Appeal, which means they cannot be removed arbitrarily (Agyeman-Duah 2005 p 3). The job security conferred by this provision means the senior members of the ECG have a stake in the success of the electoral process because if they fail they may lose their 'secured' positions. ${ }^{1}$ Describing the virtues of the Ghana ECG René Lemarchand (1998, p 2) notes that:

Over and above its mandates, the ECG has been remarkably innovative in expanding its jurisdiction to new areas in response to changing circumstances ... Although the current ECG's commissioners and the chair are presidentially-appointed, their reputation for impartiality and competence is well-established.

Another perceptive commentator sums up the credibility of the ECG thus:

1 I gained this insight from personal communication two days after the elections, on 9 December 2008, with Dr Nicholas Amponsah, who teaches political science at the University of Ghana, Legon. 
[T] he electoral commission has come to symbolize fair play, transparency, accountability, honesty, justice, independence, integrity, selflessness, openness, objectivity and strong leadership and is idolized by many institutions in Ghana and in Africa.

Adusei 2009, quoted in Zounmenou 2009, p 6

For these and related reasons Ghana's ECG has enjoyed the support of other institutional actors in the democratisation process, simplifying and aiding its work. For instance, political parties, despite all odds, have endeavoured to be democratic in their internal dealings, especially in party primaries and candidate selection (Ohman 2002). The IPAC has been particularly outstanding, providing a forum for 'building consensus on electoral issues' (Ayee 1998).

The IPAC operates at national, regional and district levels as a 'forum where representatives from all parties can articulate their grievances and disagreements openly, where they can interact with each other informally, and develop a better understanding of their respective positions' (Lemarchand 1998, p 6).

This is possibly largely because of the organisational structure of the IPAC, whose activities and processes are owned and controlled by the political parties. Although IPAC meetings are held at the premises of the ECG, the ECG only serves as a neutral coordinator of the body, providing legal guidance on the appropriateness or otherwise of the decisions of the parties. Because of this the IPAC has been able to mediate inter-party conflicts and serve as a kind of advisory body to the ECG on party matters. ${ }^{2}$

In light of its impressive performance over the years, Lemarchand (1998, p 6) concludes that: 'Today the IPAC constitutes a critically important arena for resolving differences among parties, clarifying the meaning of statutory rules, and regulations concerning their activities and raising a broad range of issues related to the electoral process.' In the thick of heightened political tensions during the period between the first round of elections in 2008 and the run-off, which was won by the NDC, the IPAC was instrumental in the signing of peace agreements between the NPP and the NDC.

Civil society, too, including local and international election observers, has played a positive role in strengthening electoral politics in Ghana over the years (Ninsin 2006). In 2008 its roles included civic education and election monitoring, thereby contributing to the overall quality of the electoral process. It should be

2 For this insight, I thank participants in a focus group discussion session held at my instance at the Institute of African Studies, University of Ghana, Legon, on 9 December 2008, where I discussed my preliminary findings as an independent research observer of the 2008 elections. I am particularly indebted to my friend Samuel Ntewusu, of the Institute of African Studies, University of Ghana, also at the time a PhD candidate at the African Studies Centre, Leiden, the Netherlands, for facilitating the forum/presentation at short notice. 
noted, however, that civil society was able to do these things because of its vastly improving democratic credentials. Internal democracy has become a referent feature of civil society organisations in Ghana, where 'the ECG is increasingly called upon to organize, supervise and validate the election of their directing organs' (Lemarchand 1998, p 6).

For this reason, 'the ECG helps institutionalize democratic procedures and contributes to the legitimacy and validity of a significant segment of Ghanaian civil society' (Lemarchand 1998, p 6). Together, these institutions have played an important role in political education and mobilisation, including the promotion of peace rallies across the country at which the message of peace and the negative implications of violence take centre stage.

From a governance perspective, Debrah (2011, p 25) attributes the success of the ECG in institutionalising good governance in the management of the electoral process and the consolidation of democracy in Ghana to three important factors:

The most distinguishing factor for the ECG's success was largely, but not exclusively, the making of the electoral process transparent, fostering agreement on the rules of the game and asserting its autonomy in relation to the performance of its mandates

Author's emphasis

Overall, there is considerable public confidence in the autonomy of the ECG, as most Ghanaians perceive it to be completely independent and not susceptible to political manipulation and interference. This is significant, given the glaring lack of trust in election management bodies (EMBs) in several other African democracies, leading to mutual suspicion among political actors/parties and in the extreme post-election violence witnessed in Nigeria, Kenya and Zimbabwe in recent times (Omotola 2010b, 2011).

Among the reasons for the trust in the ECG's autonomy are:

- It is guaranteed by law. Sufficient safeguards exist in the law to secure the operational, financial and institutional autonomy of the ECG.

- It is insulated from executive or governmental controls. Checks and balances are worked into the process of appointing its members to ensure that they are completely nonpartisan. Members of the ECG enjoy security of tenure and have the same conditions of service as justices of the superior courts.

- The ECG is in firm control of recruitment of both the permanent and temporary election staff. It controls the drafting of important legislative instruments that regulate the conduct of elections. Its budget is funded by the country's consolidated fund. 
- It has exercised its authority over setting election dates and has determined the methods of declaring election results.

- It has a relatively developed infrastructure, including, among other things, vehicles, office accommodation and communications devices that facilitate its election operations.

\section{THE ECG AND THE 2012 ELECTIONS}

This section attempts an appraisal of the performance of the ECG in the administration of the 2012 elections. In doing so it underscores three crucial aspects, namely, pre-election issues, particularly the delimitation of constituencies; the conduct of registration for the new voter register; the regulation of party finance and interparty relations and voter education; the conduct of the elections, including the deployment of election personnel and materials and security of ballots and voting as well as the collation and announcement of results and management of post-election issues, particularly the opposition's rejection of the results.

\section{Pre-election issues}

At this stage, certain issues were critical to the evaluation of the performance of the ECG in the 2012 elections. The first, and arguably one of the most vexatious, relates to the delimitation of 45 new constituencies to increase the total number of parliamentary seats to 275. The creation of these constituencies, according to the ECG Chairman, Dr Kwadwo Afari-Gyan, became inevitable following the creation of new districts by the Ministry of Local Government.

Whereas the creation of local districts was presented merely as an extension of government's decentralisation policy, emerging studies have emphasised the political economy of district creation, stressing contested interests, benefits and tensions associated with the exercise (Ayee 2012; Nyendu 2012).

In order to cater for the electoral interests of those in the new districts the ECG considered it expedient to create new constituencies in the affected areas. Thus, with the official release of the 2010 census figures, the ECG created an additional 45 electoral constituencies in October 2012 (Papran 2012).

The delimitation exercise created considerable controversy. The opposition parties, particularly the NPP, saw the move as not only politically motivated, with the active connivance of the ruling NDC, but ill-timed, coming into operation barely three months before the elections (Commonwealth Observer Group 2013). The ECG, however, regarded the creation of new electoral districts as nothing more than the fulfilment of its constitutional mandate. Article 47(1-7) of the 1992 
Constitution specifies the conditions for the establishment of new constituencies, vesting the power to do so in the ECG. Specifically, Article 47 (5) provides that:

The Electoral Commission shall review the division of Ghana into constituencies at intervals of not less than seven years, or within twelve months after the publication of the enumeration figures after the holding of a census of the population of Ghana, whichever is earlier, and may, as a result, alter the constituencies.

For many others, including the ruling party, the criticisms were baseless. Firstly, the ECG was legally competent to create the new constituencies and secondly the enabling law did not specify a specific time for the exercise of such powers, making it a discretionary power of the chairman of the ECG. In addition, the NPP had done the same in 2000 when the ECG had created an additional 30 constituencies to bring the total to 230 in defiance of the opposition's objections (Hiadzie 2012; Darko 2012).

The matter was put to rest by a Supreme Court judgement in October 2012 upholding the ECG's decision. Though legally correct and binding, the decision constituted one of the bases of mutual suspicion, especially between the two leading parties, the NDC and the NPP, that fuelled adversarial behaviour during and after the elections. One may be tempted to argue that, while legally valid, it was not particularly politically expedient at the time, given that the results of the 2008 presidential election were so close that a run-off election was necessary.

The ECG's insistence on creating the new constituencies could be seen as an error of judgement. If it had waited until after the election it might have averted the legitimacy crisis relating to the electoral outcome.

Voter registration is another important indicator of the level of preparedness for an election. If well handled and credible it helps promote popular trust in the electoral process and outcome. The creation of a new voter register was necessary, given widespread suspicion that the previous register was bloated. At the onset of the 2008 exercise it was expected that between 600000 and 800000 new voters would be registered. In fact, the figure was 1835 417, giving rise to suspicions that there had been foul play and calling into question the competence of the ECG (Commonwealth Observer Group 2013, p 6).

In order to salvage its reputation the ECG introduced a biometric system of registration, a move aimed at preventing double registration, thereby eliminating ghost names from the register. It also prescribed various penalties for violations. For instance, double registration warrants a jail term and, if it involves an electoral officer, such an officer will not only be dismissed, he or she will be prosecuted. While the exercise reportedly went well despite allegations of the registration 
of underage persons, the technical challenges it generated during the elections were its undoing.

Table 1

Number of registered voters, constituencies and polling stations by region 2012

\begin{tabular}{|l|c|c|c|}
\hline Region & Registered voters & Constituencies & Polling stations \\
\hline Greater Accra & 2792576 & 34 & 4114 \\
\hline Ashanti & 2557122 & 47 & 4628 \\
\hline Eastern & 1429682 & 33 & 2961 \\
\hline Western & 1425158 & 26 & 2618 \\
\hline Northern & 1263462 & 31 & 2386 \\
\hline Brong-Ahafo & 1245954 & 29 & 2740 \\
\hline Central & 1231513 & 23 & 2192 \\
\hline Volta & 1156740 & 26 & 2283 \\
\hline Upper East & 565097 & 15 & 1136 \\
\hline Upper West & 364489 & 11 & 944 \\
\hline Total & 14031793 & 275 & 26002 \\
\hline
\end{tabular}

Sources: EC2012a; EISA 2012

As Table 1 shows, at the end of the exercise a total of 14031793 eligible voters were registered across the 275 constituencies and 26002 polling stations. Despite all claims to the contrary, the validity of these figures can be challenged. The difference between the 2008 and 2012 figures is too exponential and questionable. One cannot totally rule out double or even, in extreme cases, multiple registrations. The ECG chairman allegedly admitted, when confronted with evidence in the course of cross examination in the Supreme Court in the suit challenging the presidential election results, to several cases of double registration in the 2012 register (Graphic 2013).

The question of voter education is also very important. If well handled it can help to galvanise the level of political participation in terms of both quantity and quality. Over the years the ECG has paid attention to voter education. However, there are indications that it has been inadequate or ineffective, as evidenced by the large percentage of rejected/spoilt ballots.

A situation in which spoilt ballots come third in a presidential election contested by seven parties and an independent candidate is an indication of a fundamental flaw in the voter education process. To illustrate, in the first round 
of the 2008 presidential election Nana Akufo-Addo of the NPP won 4159439 (49.13\%) of the vote and John Atta Mills of the NDC 4056634 (47.92\%). They were followed by Papa Kwesi Nduom of the CPP, with $111494(1.34 \%)$ of the valid votes cast, far below the number of rejected ballots, which was 205438 (2.4\%) (Omotola 2010).

Table 2

Rejected/Spoilt Ballots as a Percentage of Total Votes Cast 1992-2012

\begin{tabular}{|l|r|r|r|r|r|r|}
\hline \multirow{2}{*}{ Year } & \multicolumn{4}{|c|}{ Number } & \multicolumn{2}{c|}{ Percentage } \\
\cline { 2 - 8 } & Registered & Votes cast & Valid votes & $\begin{array}{c}\text { Invalid } \\
\text { votes }\end{array}$ & Turnout & Invalid \\
\hline 2012 & 14158890 & 11246982 & 10995262 & 251720 & 79.43 & 2.24 \\
\hline 2008 & 12532758 & 8897937 & 8691941 & 205996 & 71.00 & 2.32 \\
\hline 2004 & 10354970 & 8813908 & 8625785 & 188123 & 85.12 & 2.13 \\
\hline 2000 & 10698652 & 6605084 & 6500870 & 104214 & 61.74 & 1.58 \\
\hline 1996 & 9279605 & 7256872 & 7145764 & 111108 & 78.20 & 1.53 \\
\hline 1992 & 7401370 & 2126918 & 2062564 & 64354 & 28.74 & 3.03 \\
\hline
\end{tabular}

Sources: ECG 2012b; EISA 2013

As can be seen from Table 2 there has been a high level of spoilt/ rejected ballots in Ghanaian elections since 1992, oscillating between 1.5\% and 3.03\% and standing at $2.24 \%$ ( 251720 ballot papers) in the 2012 elections. There is a need for enhanced political education, especially with regard to the handling of ballot papers.

Finally, the oil question (see Van Gyampo 2012 and Nyuykonge \& Letsoalo on page 115 of this issue). also played a significant role, especially during the party campaigns. Oil automatically raised the electoral stakes, becoming the central theme of the campaigns of the two leading parties. The emphasis of both parties was on what should be done and not done with oil receipts.

\section{Conduct of the elections}

As usual, the ECG made an effort to ensure the smooth conduct of the elections. The stage was set with the early deployment of election officials and materials. According to the reports of election observation groups, both domestic and international, the elections generally went well, with substantial compliance with the electoral rules. 
The Coalition of Domestic Election Observers (CODEO), which conducted parallel vote tabulation (PVT) as part of its overall effort to observe the 2012 elections, returned a positive verdict (CODEO 2012a). The Economic Community of West African States (ECOWAS) group, led by Chief Olusegun Obasanjo, Nigeria's former president, declared the election well administered. The Commonwealth Observer Group (COG 2013) reported that in most places voting was well administered and voters were free to exercise their rights.

It attributes this success in part to the presence of party agents 'in virtually all stations, providing for transparency and accountability'. The process of vote counting, tabulation and the announcement of results was also said to be transparent and credible.

The vote count at the polling stations was transparent, with party agents able to follow the process closely. This was also the case during the tabulation process. At the polling station level party agents were able to get a copy of the results and could therefore check and verify the results later tabulated and announced at the constituency and national levels. Results from polling stations and constituencies were also broadcast extensively on TV, radio and online, enabling people to follow on an on-going basis as the final results of the 2012 election were calculated

Commonwealth Observer Group 2013, p 52

This view was corroborated by CODEO (2012a, p 2), whose report 'confidently confirms that the results of its PVT are consistent with the official presidential results announced by the Electoral Commission', thereby boosting its 'confidence that the results of the 2012 presidential polls declared by the Electoral Commission are generally an accurate reflection of how Ghanaians voted in the December 7 polls'.

However, there was another side to the administration of the elections on the election days and it was this that led to the rejection of the result of the presidential election by the NPP (Daily Guide, 12 December 2012; BBC Africa News, 9 December 2012). The official results indicate that the incumbent, President John Mahama of the NDC, won 5574761 (50.70\%) of the total vote against $5248898(47.74 \%)$ for Nana Akufo Ado. The NDC also won 145 of the 275 parliamentary seats, while the NPP won 123 (Gyimah-Baodi 2013, p 5), leaving only 15 for other parties and independent candidates.

The NPP rejected the results and went to court to challenge the outcome of the presidential election and more than $10 \%$ of the parliamentary election results. The rejection was predicated upon what the party called monumental irregularities and the ECG's failure to comply with important aspects of the electoral regulations. 
Table 3

Ghana Election 2012: Presidential Results

\begin{tabular}{|l|c|c|c|}
\hline Candidate & Votes obtained & Percent votes & Rank \\
\hline John Dramani Mahama (NDC) & 5574761 & 50.70 & 1 \\
\hline Nana Akufo Addo (NPP) & 5248898 & 47.74 & 2 \\
\hline Papa Kwesi Nduom (PPP) & 64362 & 0.59 & 3 \\
\hline Dr. Henry Herbert Lartey (GCPP) & 38223 & 0.35 & 4 \\
\hline Hassan Ayariga (PNC) & 24617 & 0.22 & 5 \\
\hline Michael Abu Sakara Foster (CPP) & 20323 & 0.18 & 6 \\
\hline Jacob Osei Yeboah (Independent) & 15201 & 0.14 & 7 \\
\hline Akwasi Addai Odike (UFP) & 8877 & 0.08 & 8 \\
\hline
\end{tabular}

Sources: ECG 2012a; African Elections Project 2012

The first and most basic of the NPP's bases of rejection related to the technical hitches encountered in the application of the biometric voter equipment. On page 20 of its manual for candidates and their agents the ECG states:

On Election Day, all voters will be verified/identified by their biometric details in the Voters' Register. Voters' fingerprints will be scanned on a voter verification machine and compared with their details in the Voters' Register. The verification of voters is to ensure that only persons on the voters' roll in each polling station are allowed to cast their ballots on Election Day.

Quoted in Damptey 2013, p 3

At a press conference on Wednesday 5 December 2012 to reassure Ghanaians that the ECG was prepared to conduct free, fair and credible elections, the ECG chairman reiterated that all prospective voters should make themselves available for verification, without which they would not be allowed to vote. As he put it, 'among the decisions we have taken with the political parties is "NVNV-No Verification, No Voting", and by verification we mean that everybody would have to be verified biometrically' (quoted in African Elections Project 2012, p 1).

The achievement of this goal depends entirely on the effectiveness of the biometric voting equipment. Unfortunately, the equipment, according to CODEO (2012b, cited in Gyimah-Boadi 2013, p 5), 'malfunctioned in almost a fifth of the polling stations in the country and in about a third of the polling stations in Greater Accra'. 
The implications of this development were generally negative. Firstly, it meant that for the first time since 1992 the voting period had to be extended beyond the traditional one day and voting took place over two days. While the extension may be seen as a way of accommodating as many eligible voters as possible, it must also have come at a cost. For instance, were polling officers in affected areas originally recruited to work for two days? How many eligible voters had the patience to wait for two days in order to exercise their right to vote?

Secondly, there were allegations that double standards were applied, with some allegedly allowed to vote without biometric voter verification, while others were not. Worse still, this discriminatory practice was said to have favoured the ruling party to the disadvantage of the opposition.

Other notable sources of dissatisfaction with the conduct of the elections included the failure of presiding officers at some polling stations to sign the official results sheet, over-voting at a number of polling stations and discrepancies in the size of the voters' register. The Supreme Court judgement, which upheld the victory of Mahama's NDC, would appear to have finally put to rest the controversies that surrounded the results, particularly since all the political actors, particularly the main opposition NPP, graciously accepted the verdict in good faith. Contrary to pre-judgement tensions, the judicial outcome did not generate post-judicial violence in the country.

These shortcomings notwithstanding, the ECG was generally considered to have administered the elections well, as attested to by the reports of local and international election observer groups.

\section{POST-ELECTION CHALLENGES}

The pronouncement of election results does not signify the end of an election. The responses to the outcome by critical stakeholders, including the candidates and their parties, the electorate, civil society and election observers, are also important. These actors confer the seal of legitimacy on the electoral process by expressing satisfaction with the process and its outcome. The danger is that negative verdicts are treated as sacrosanct and tend generally to discredit the election.

Often the opposition may raise a false alarm to generate public sympathy both locally and internationally. Staffan Lindberg (2004, p 64) underscores this possibility when he notes that the opposition's rejection of results may be a strategy to undermine the political rule of its rivals. He therefore warns that 'challenge to the official results cannot be taken at face value as substantiating allegations of irregularities'.

One viable way to establish the veracity or otherwise of such claims is through legally sanctioned institutional frameworks, particularly the courts. The legitimacy 
of the litigation process also requires the full cooperation of the ECG, especially in making necessary electoral materials available to the litigant (in the most recent case, the NPP) so that it can argue its case. In doing so the ECG demonstrates its political neutrality and impartiality and can contend that if anything went wrong it was a genuine mistake.

The ECG appears in the recent case, despite allegations and counter allegations (see Appiah 2013), to have done its best to assist the court process. Its lawyers and its chairman appeared before the court and complied substantially with court directives.

It is important that Ghanaians, irrespective of party affiliation, continue to trust the Supreme Court to mete out justice without fear or favour. As it has turned out, both parties have responded well to the court's decision to uphold the victory of Mahama's NDC.

The ECG, however, needs to do more in terms of post-election peacebuilding through a sustainable process of social mobilisation and voter education on the need to eschew violence. In this regard, civil society has taken the lead through peace advocacy. Efforts must be intensified to sustain the peace process.

\section{CONCLUSION}

The primary objective of this article was to assess critically the role of the ECG in the administration of the 2012 elections. This could be done in a number of ways. On the one hand, the overall quality of the elections, measured by the level of participation, competitiveness and legitimacy, sheds some light on the performance of the ECG. The reports of domestic and international observers groups, media reportage and specific features of the election results can be useful in this regard.

Assessed this way, the ECG may be judged to have done very well, especially on the first two indicators, given the high level of voter turnout as an important indicator of participation and the closeness of the total number of votes and seats won by the ruling NDC and its main opposition, the NPP. However, the legitimacy of the election was fiercely challenged by the opposition's rejection of the results and the attendant litigation.

On the other, the performance of the ECG could be assessed by examining its action and inaction at critical stages of the electoral cycle - before, during and after the elections, underscoring how this enabled or disabled the electoral process. The ECG may also be assessed through public perception and trust in its electoral activities during the period under review. This will require an extensive survey among various stakeholders using a variety of data-collection methods, including questionnaires, focus group discussions and interviews. It is also possible to combine two or all of these approaches in measuring the performance of the ECG. 
In this article a combination of the first two approaches has been adopted. The overall quality of the elections, as shown above, portrays the ECG in a relatively positive light. However, the rejection of the result by the NPP constituted an affront to the institutional integrity, competence, professionalism and political impartiality that needs to be proved beyond any reasonable doubt.

As the analysis reveals, a number of factors, some of which can be directly linked to the ECG, could have aided the disposition of NPP to the election results. Firstly, the official commencement of oil exploitation in 2010 meant access to huge oil revenues. Since access to political power amounts to access to these oil revenues, it was only natural that the oil question would play a significant role in the election process.

Gyimah-Boadi (2012, p 104) reinforces this position when he asserts that 'early indications suggest that oil will exacerbate the unhealthy partisanship and "competitive clientelism" that plague Ghanaian politics'. And so it happened, because 'partisan politics has been woven into Ghana's oil story from the moment the Jubilee discovery was announced'. In short, the tensions associated with the 2012 election were, in large part, a signifier of the desire by both parties to control oil windfall/revenues.

Secondly, while the ECG cannot be directly linked to the oil question, some of its actions had an impact on the overall quality of the election. Two of these are critical. One is the BVR and the subsequent NVNV requirement for voting that became deeply messy as a result of the malfunctioning of the biometric voter equipment on election day. While technical problems are inevitable with machines, the handling of such challenges in a way that promotes fairness and equity is important. Unfortunately, this would appear not to have been the case.

The development was allegedly exploited by electoral officials to promote double standards, allowing some to vote without verification and denying others the opportunity. The second action, the delimitation of 45 new constituencies, while it is within the statutory powers of the ECG, would appear to have been ill timed. It came barely three months before the election, leaving room for suspicion among opposition parties that it was nothing more than gerrymandering.

The inability to address these pre-election issues effectively and to disperse the associated tensions contributed to a resort to adversarial behaviour by key political actors across party divides. This accentuated distrust among competing political parties and actors, manifested in the resort to vulgar political language and inciting statements.

For example, while the NPP presidential candidate, Nana Akufo-Addo, 'urged his party's supporters not to be intimidated by the NDC's muscular tactics, but to be prepared to fight to the death if need be', the ruling NDC would appear to have taken the use of vulgar language to the extreme by announcing 
'the creation of a "Heroes Fund" for party supporters (or their families) who are injured or die "in the service of the party"' (quoted in Gyimah-Boadi 2012, p 106). Such a decision could be taken as a form of insurance to embolden people in their resolve to resort to violence at the slightest provocation.

On the whole, it seems these are not heady days for Ghana's democracy. While it has been touted in recent times as a regional African model, developments surrounding the 2012 election give cause for concern and raise questions, if not doubts, about the institutional abilities and professionalism of the ECG.

Since the chairman of the ECG is widely considered to be a person of high integrity and competence, critical eyebrows can be raised about the quality of his supporting and ad hoc staff, especially those deployed during the 2012 elections. With the impending retirement of the chairman only time will tell how the new leadership (and the discovery of oil) will shape the future of the politics of Ghana. These are crucial issues that must not be trivialised.

\section{- REFERENCES -}

Adusei, L A. 2009. 'Electoral Commission and Dr. Afari Gyan deserve a Nobel Peace Prize'. Available at: www.modernghana.com/news/220114/1/ electoral-commission.dr.afari-gyan-deserve.nob.html

African Elections Project. 2012. 'Ghana - No Verification No Vote - Electoral Commission'. Available at: allafrica.com/stories / 201212061756.html

Afrobarometer, 2006. Afrobarometer Round 3: The Quality of Democracy and Governance in 18 African Countries, A publication of Afrobarometer, Michigan State University, USA.

Agyeman-Duah, B. 2005. 'Elections and Electoral Politics in Ghana's Fourth Republic'. Critical Perspective18, CDD-Ghana, July.

Appiah, E. 2013. 'NPP Accuses Electoral Commission of Hiding Evidence', 26 April. Available at: politics.myjoyonline.com/pages/news/201304/105048.php Ayee, J R A. 1998. 'Elite Consensus and Democratic Consolidation in Ghana: The Inter-Party Advisory Committee (IPAC)'. In J R A Ayee (ed). The 1996 General Elections and Democratic Consolidation in Ghana. Legon, Ghana: Department of Political Science, University of Ghana.

Ayee, J R. 2012. 'The Political Economy of the Creation of Districts in Ghana'.Journal of Asian and African Studies, Online version, 7 December.

BBC News Africa. 2012. 'Ghana election: Opposition NPP alleges vote fraud', 9December. Availableat: www.bbc.co.uk/news/world-africa-20660228

Boafo-Arthur, K. 2006. 'The 2004 General Elections: An Overview'. In K BoafoArthur (ed). Voting for Democracy in Ghana: The 2004 Elections in Perspective Vol 1. Accra: Freedom Publications. 
CODEO. 2012a. 'CODEO's Statement on the Official 2012 Presidential Results', 10 December. Available at: codeoghana.org/images/CODEO $\% 20 \mathrm{PVT} \% 20$ Statement $\%$ 20(FINAL-FINAL-Final\%20)-2012.-1.pdf

CODEO. 2012b. 'CODEO Close of Polls Statement', 7 December. Available at: www.cddghana.org/_upload/general/file/CODEO $\%$ 20CLOSE\%20OF\%20 POLLS\%20STATEMENT\%20final.pdf

Commonwealth Observer Group. 2013. Ghana Presidential and Parliamentary Elections, 7 December 2012.London: Commonwealth Observer Group.

Daily Guide. 2012a. 'Ghana Elections 2012: NPP Rejects Results', 12 December. Available at: www.modernghana.com/news/435422/1/ghana-elections2012-npp-rejects-results.html

Damptey, D D. 2013. 'Election 2012: The Greatest Fraud against Ghana'. Available at: www.spyghana.com/election-2012-the-greatest-fraud-against-ghana/

Darko, O. 2012. 'Is the ECG Right in Creating 45 New Constituencies this Time?'. Available at: www.ghanaweb.com/GhanaHomePage/features/artikel. php?ID=249207

Debrah, E, F K Asante and E Gyimah-Boadi. 2010. A Study of Ghana's Electoral Commission. Dakar, Senegal: CODESRIA.

Debrah, E. 2011. 'Measuring Governance Institutions' Success in Ghana: The Case of the Electoral Commission, 1993-2008'. African Studies 70 (1).

Electoral Commission of Ghana. 2012a. 'Basic Regional Electoral Statistics as at 13th Nov. 2012'. Available at: www.results.ec.gov.gh/assets/Copy $\% 20$ of $\% 20$ tblSummaries(1).xls

Electoral Commission of Ghana. 2012b. 'National Summary of Rejected Ballots, 1992-2008'. Available at: www.results.ec.gov.gh/assets/Copy $\% 20$ of $\% 20$ tblSummaries(1).xls

Electoral Commission of Ghana. 2013. Available at: www.ec.gov.gh/index.php Electoral Institute of South Africa (EISA). 2012. 'Ghana: 2012 elections registered voters, constituencies and polling stations statistics by region'. Available at: www.eisa.org.za/WEP/gha2012registration.htm

EISA. 2013. 'Ghana: Voting statistics overview 1992-2012'. Available at: www.eisa. org.za/WEP/ghastats.htm

Elklit, J \& A Reynolds. 2002. 'The Impact of Election Administration on the Legitimacy of Emerging Democracies: A New Comparative Politics Research Agenda'. Commonwealth and Comparative Politics 40(2).

Freempong, A K D. 2008. 'Innovations in Electoral Politics in Ghana's Fourth Republic: An Analysis'. In R Ciska (ed). Democratic Innovation in the South: Participation and Representation in Asia, Africa and Latin America. Buenos Aires: CLASCO Books.

Gadzekpo, A. 2000.'Reflections on Ghana's Recent Elections'. Review of African Political Economy 88. 
Gary, I. 2010. Ghana's Big Test: Oil's Challenge to Democratic Development. Washington, DC: Oxfam America and Idosec.

Graphic. 2012. 'Afari-Gyan Admits to Double Registration in 2012 Voters Register', 6 June. Available at:www.modernghana.com/news / 467465 / 1 / afari-gyanadmits-to-double-registratio.html

Gyimah-Boadi, E. 1994. 'Ghana's Uncertain Political Opening'. Journal of Democracy $5(2)$.

Gyimah-Boadi, E. 2001. 'A Peaceful Turnover in Ghana'. Journal of Democracy 12(2).

Gyimah-Boadi, E. 2009. 'Another step forward for Ghana'. Journal of Democracy 20(2).

Gyimah-Boadi, E. 2012. 'Oil, Politics and Ghana's Democracy'.Journal of Democracy 23(3).

Gyimah-Boadi, E. 2013. Strengthening Democratic Governance in Ghana: Proposals for Intervention and Reform. A Publication of STAR-Ghana, Strengthening Transparency, Accountability and Responsiveness in Ghana. Available at: www.starghana.org/assets/STAR-Ghana $\% 20-\% 20$ Scoping $\% 20$ Study $\% 20$ for\%20strengthening\%20Democratic\%20Governance\%20in\%20Ghana.pdf Gyimah-Boadi, E \& V Brobbey. 2012. 'Countries at the Crossroads 2012: Ghana'. Available at: www.freedomhouse.org/sites/default/files/Ghana\%20-\%20 FINAL.pdf

Harvey, R. 2010. 'Will Oil Build or Break the Back of Ghana's Democracy'. Policy Briefing 14, Governance of Africa's Research Programme. South African Institute of International Affairs (SAIIA).

Hiadzie, R. 2012. 'The Creation of 45 New Constituencies: What is the Fuss About?', 2 October. Available at: www.modernghana.com/news/421224/1/thecreation-of-45-new-constituencies-what-is-the-.html

Lemarchand, R. 1998. 'Ghana's Electoral Commission Provides Regional Model'. African Voices: A Newsletter on Democracy and Governance in Africa 7(1), Winter/Spring.

Lindberg, S I. 2004. 'The Democratic Qualities of Competitive Elections: Participation, Competition and legitimacy in Africa'. Commonwealth and Comparative Politics 42(1).

Ninsin, K A. 2006. 'Institutional Development and Democratic Consolidation'. In K Boafo-Arthur (ed). Voting for Democracy in Ghana: The 2004 Elections in Perspective Vol 1. Accra: Freedom Publications.

Nugent, P. 2001. 'Winners, Losers and also Rans: Money, Moral Authority and Voting Patterns in the Ghana 2000 Election'. African Affairs 100(400).

Nugent, P. 2005. 'Banknotes and Symbolic Capital: Ghana Elections under the Fourth Republic'. Mimeo, Center of African Studies, University of Edinburgh, Scotland. 
Nyendu, M. 2012. 'Democratic Decentralization in Ghana: The Need for Policy Review'. Journal of Asian and African Studies 47(2).

Obeng-Odoom, F. 2012. 'Problematising the Resource Curse Thesis'. Development and Society 41(1).

Ohman, M. 2002. 'Determining the Contestants: Candidate Selection in Ghana's 2000 Election'. Critical Perspective 8, January.

Omotola, J S. 2010a. 'Ghana Defies the Odds Again: The 2008 Elections and the Consolidation of Democracy'. Politeia: South African Journal of Political and Administrative Studies 29(1).

Omotola, J S. 2010b. 'Mechanisms of Post-Election Conflict Resolution in Africa's "New" Democracies'. African Security Review 19(2).

Omotola, J S. 2011. 'Explaining Electoral Violence in Africa's New Democracies'. African Journal on Conflict Resolution 10(3).

Omotola, J S. 2012. 'Election Administration and Democratic Consolidation in Ghana and Nigeria under the Fourth Republic'. Unpublished PhD thesis, Department of Political Science, University of Ibadan, Nigeria.

Oquaye, M. 1995. 'The Ghanaian Elections of 1992: A Dissenting View'. African Affairs 94(375).

Oquaye, M. 2000. 'The Process of Democratisation in Contemporary Ghana'. Commonwealth and Comparative Politics 38(3).

Van Gyampo, R E. 2011. 'Saving Ghana from its Oil: A Critical Assessment of Preparations so Far Made'. Africa Today 57(4).

Papran, B. 2012. 'Controversy over the Creation of 45 New Constituencies', 18 October. Available at: www.modernghana.com/news / 424647/1/ controversy-over-the-creation-of-45-new-constituen.html

Rakner, L \& L Svasand. 2003. 'Uncertainty as a Strategy: Electoral Processes in Zambia 1991-2001'. Working Article 2003: 13 Chr. Michelson Institute Development Studies and Human Rights, Norway. Available at: www.cmi. no/public/public.htm.

Smith, D A. 2002. 'Consolidating Democracy? The Structural Underpinnings of Ghana's 2000 Elections'. Journal of Modern African Studies 40(4).

Walraven, K V. 2002. 'The End of an Era: The Ghanaian Elections of December 2000'. Journal of Contemporary African Studies 20(2).

Whitfield, L. 2009. " "Change for a Better Ghana": Party Competition, Institutionalization and Alternation in Ghana's 2008 Election'. African Affairs 108(433).

Zounmenou, D. 2009. ‘Ghana's 2008 Elections: Towards a Consolidated Democracy'. ISS Situation Report, South Africa, issued 27 July. 